\title{
COMPARATIVE ASSESSMENT OF WATER INSULATIONS AGAINST SUBSOIL WATER
}

\author{
Annamária Dudás ${ }^{1}$ \\ Valéria V. Horn ${ }^{2}$ \\ Tamás Balla ${ }^{2}$ \\ Mátyás Ress ${ }^{4}$
}

UDK: 699,82

DOI: $10.14415 /$ konferencijaGFS2019.043

Summary: In construction practice bituminous membranes and PVC sheets are most often used for the preparation of waterproofings against subsoil water. The realization of the watertight connections of these sheets defines the durability and the efficiency of the insulation. Nowadays, high-quality flexible waterproofing coatings are also available, the use of which is an alternative to conventional membrane constructions. Waterproofing can be ensured by surface protection of watertight reinforced concrete structures with coating insulation. The article analyzes and compares these solutions according to building structure, construction cost and construction time.

Keywords: waterproofing, subsoil water, waterproofing coating, watertight concrete

\section{INTRODUCTION}

There are reliable traditional solutions for insulating buildings against groundwater. Specialized construction companies can realize waterproofing for the same duration as the lifetime of the building. In Hungary the value of construction sites and areas in cities, especially in the capital and in the agglomeration has increased significantly over the past few years. Demand is increasing for residential properties, especially for condominiums. Accordingly, construction companies use free building sites or vacant lots to fulfill these needs. It is a frequent request from constructors to establish a basement level, whether for garages, storage, hobby, sports or wellness facilities. However, the finished floor level of the basement often got to below the subsoil water level, so it has an impact on the design of the whole building.

\footnotetext{
${ }^{1}$ AnnamáriaDudás, PhD civil eng., associate professor of Budapest University of Technology and Economics, Faculty of Civil Engineering, Department of Construction Materials and Technologies, H-1111 Budapest, Hungary, tel: +36146323 73, e - mail: dudas.annamaria@epito.bme.hu

${ }^{2}$ Valéria V. Horn, DLA, architect, assistant professor of Budapest University of Technology and Economics, Faculty of Civil Engineering, Department of Construction Materials and Technologies, H-1111 Budapest, Hungary, tel: +36146323 73, e - mail: horn.valeria@epito.bme.hu

${ }^{3}$ Tamás Balla, BSc civil eng., e - mail: ifjballa.tamas@gmail.com

${ }^{4}$ Mátyás Ress , MSc civil eng., e - mail: ressmatyas@gmail.com
} 


\section{THE ROLES OF WATERPROOFING AGAINST SUBSOIL WATER AND EXPECTATIONS}

The role of water insulation against subsoil water is to protect insulated structures and interiors from subsoil water that is constantly or intermittently present and from all its harmful effects.

Expectations of waterproofings:

- Constructed as a connected and continuous structure.

-Always be placed between two solid, displacement-free structures.

-Hydrostatic pressure is always balanced by a calculated load-bearing building structure.

-The load must be tolerated without deteriorating the insulation value.

-The upper plane of the subsoil water insulation must be the determined subsoil water level, from which to the upper it is sufficient to prepare the insulation against soil moisture.

-The substrate of the waterproofing must be sufficiently resistant to aggressive groundwater, if it is necessary. [1, 2]

Waterproofing, highly watertight and watertight waterproofing are available with insulation against subsoil water.

The insulation is inseparable from the insulation substrate and its protection, and it is coupled with the fittings of pipe penetrations, with the expanding tapes for working joints, with the dilatation profiles, and with the strengthening profile of the corners.

The main characteristics of the insulating boards are: load-bearing capacity (compression strength), tensile strength, tear elongation, bending in cold, heat resistance, wearing material of the memrane. [3]

\section{Modified bitumenous membrane insulation}

The number of layers is determined by the depth of the water immersion, but even with a small immersion depth, two layers must be installed. The insulation requires a smooth surface of the substructure and the first layer is laid on a primer. Modification is carried out with plastomers and elastomers that determine the above mentioned properties. [1, 34]

\section{Plastic insulation}

For the subsoil water pressure plastomer membranes are mainly used. The most important of these are PVC, polyisobutylene (PIB), ethylene copolymer bitumen (ECB), ethylene vinyl acetate copolymer (EVA).

The plastic membranes have serious demands on the base surface. They always require a smooth surface, the plate must be separated from the supporting structure, eg. with plastic felt and the insulation must be protected. This involves the installation of a semirigid PVC layer on the PVC membrane. The upper horizontal closure of the plate can be formed by a line-like mechanical fastening, which may be an aluminum strip or a preformed zink band. The endlessness of the membranes can be prepared by solvent based or hot air welding. [1, 4-7] 
Contemporary achievements in civil engineering 23-24. April 2019. Subotica, SERBIA

\section{Insulation coating}

The use of coating insulation against subsoil water pressure is less common than membrane insulations.

The coating insulations are applied on the substrate in a plastic state and then become water insulation during the chemical and/or physical process. They form a homogeneous, seamless coating. They require a crack-free substructure.

Masses

The masses are applied in two layers with a thickness of 2.5-5 mm up to a water column height of $10 \mathrm{~m}$. These water insulation masses may contain modified bitumen and additives, moreover resins, tar, fillers.

Mortars

Mortar insulation is applied in several layers with a layer thickness of 1-10 mm up to a height of $10 \mathrm{~m}$ water table level. These mortars are a mixture of cement, cement and resin, or a mixture of plastic binder and special additives, in a compound of one or more components. [8]

\section{Mass concrete}

The watertightness of the mass concrete is ensured by the reinforced concrete structure itself, due to the cristals, which fill the pores of the material. Only relative dryness requirement can be achieved with this solution. The structural thickness can be determined according to the composition of the concrete, the method of preparation and the requirements. The minimum thickness is $30 \mathrm{~cm}$ for the horizontal, $20 \mathrm{~cm}$ for the vertical structures [7]. The water tightness of the concrete is determined by the size and arrangement of the pores [9].

\section{VARIATIONS}

The basement of a single-family house, as a sample building (Fig. 1), was examined with the following waterproofings:

-Bitumenous membrane insulation against subsoil water (ISO-LINE NEGRO PLAST C4,5) [4]

-Plastic membrane insulation against subsoil water (FATRAFOL 803) [5]

-Coating insulation (AQUAFIN-2K/M) against subsoil water on watertight concrete. [10]

All three materials can be considered very good in their category. The base condition is that the cellar is subjected to the requirement of total (powder) dryness, so the water insulation must meet the waterproofing requirement. The comparison is made on the basis of time and cost of construction.

Bituminous membrane insulation is reinforced by a polyester felt and it is built in two layers torch-welded on the full surface, on an appropriately based substructure, with joints and overlaps according to the application specifications (Fig.2).

The 1.5-mm-thick PVC membrane is built on geotextile separator layer and the connections are made with hot air welding (Fig.2). 


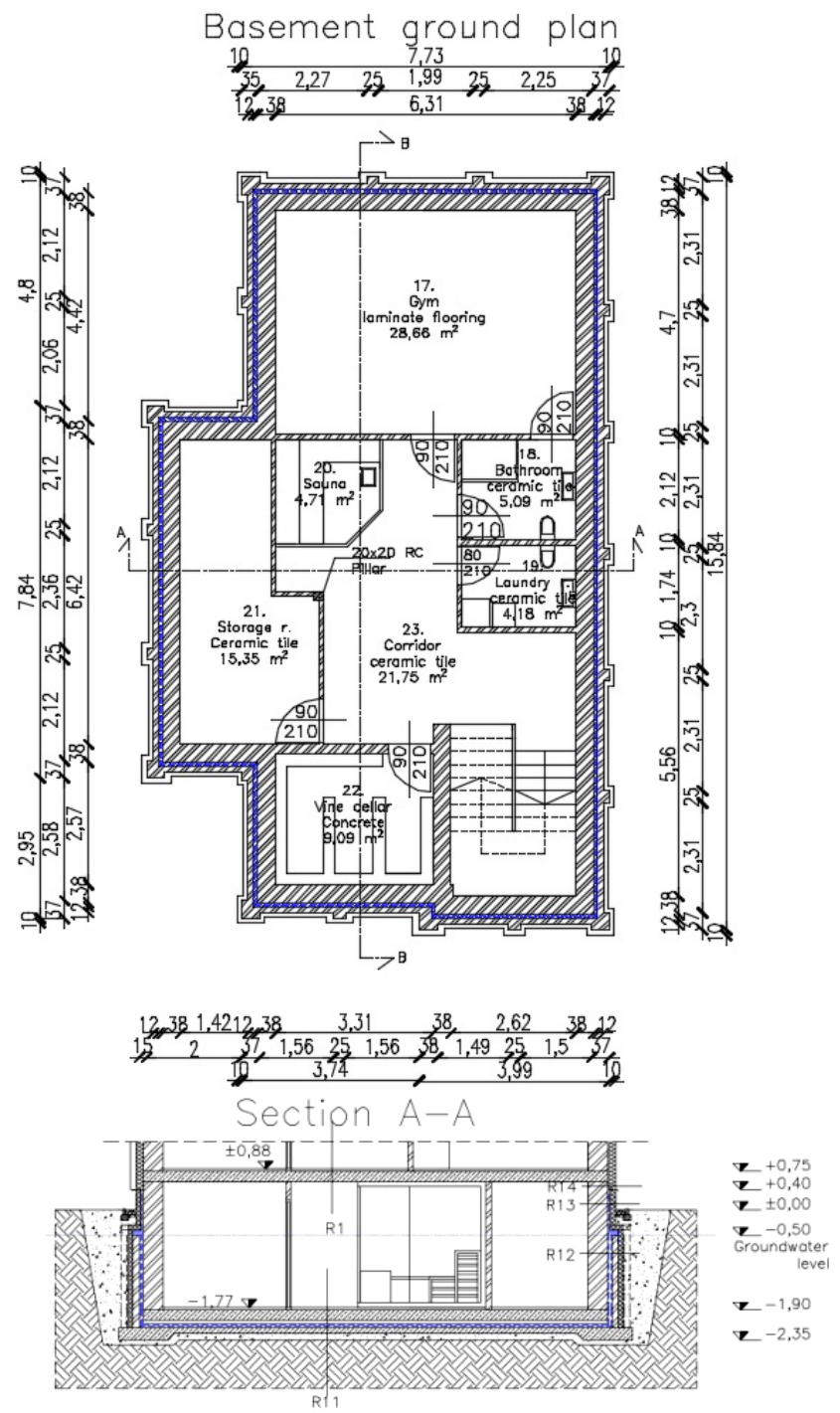

Figure 1. Ground plan of basement and part of the cross-section of the sample singlefamily house

\section{Coating insulation against subsoil water on watertight concrete}

AQUAFIN-2K/M is a flexible, elastomeric, two-component, polymer-modified cementbased coating that forms a water insulation and protective layer on concrete with a significant crack-bridging capability. In case of groundwater pressure, three layers must be applied (material consumption: $3 \times 1.76 \mathrm{~kg} / \mathrm{m}^{2}$ ). It can be used on both positive and negative sides. In case of negative side waterproofing, two layers of AQUAFIN-1K rigid waterproofing material must be placed underneath ( $\left.2 \mathrm{x} 2 \mathrm{~kg} / \mathrm{m}^{2}\right)$. [10] (Fig.2) 


\section{$7^{\text {th }}$ INTERNATIONAL CONFERENCE}

Contemporary achievements in civil engineering 23-24. April 2019. Subotica, SERBIA

The additive for Watertight Concrete (WTC) is the BETOCRETE CL210-WP crystalline insulating and hydrophobizing material. The insulating material reacts with the free lime content of the concrete material structure to form crystals in the pores of the structure, therefore sealing them. With its application, it is continuously active, and creates a subsequent crack-closing up to $0.4 \mathrm{~mm}$ with its self-healing process. The structure can withstand extremely high hydrostatic pressure, and the additive increases the final strength of the concrete. [11]
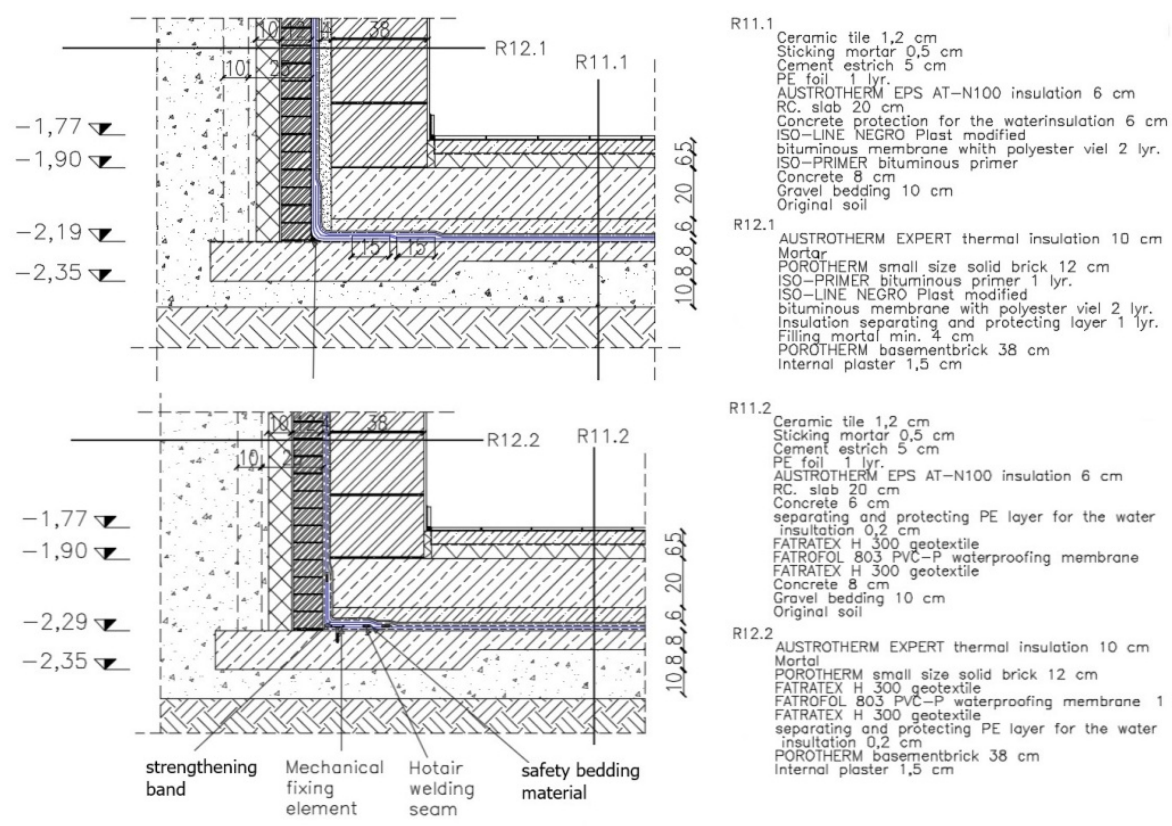

R11.2
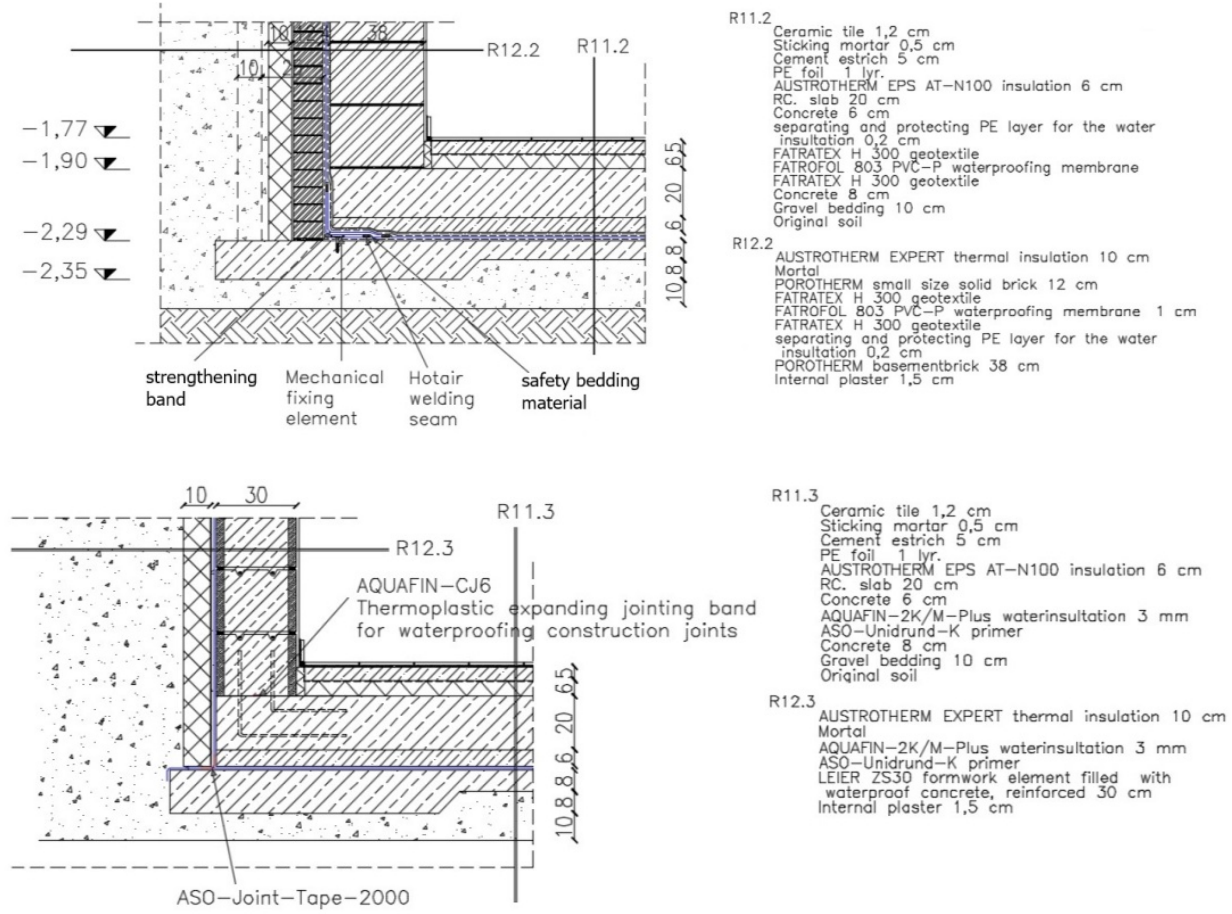

Figure 2. Details of the mat foundation and the 3 water insulation variations for the effect of subsoil water 


\section{COMPARISON OF WATERPROOFING SOLUTIONS FOR CONSTRUCTION TIME}

The construction schedule were prepared for each of the three water insulation versions, therefore the duration of the construction was determined (Fig. 3).

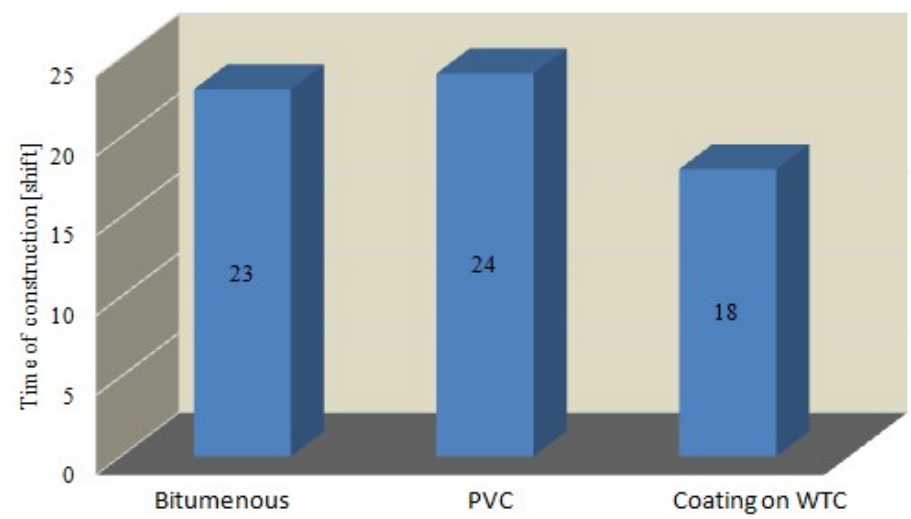

Figure 3. Comparison of water insulations by construction time

It is visible from the construction schedules and the workload calculations that the time of masonry and other masonry works need 9 shifts at membrane insulations (total of cellar wall and insulation supporting wall), while 10 shifts at the case of coating insulation and watertight concrete. Thus, the difference of 5-6 shifts between the membrane insulations and the coating insulation is clearly given due to the construction time of the insulation. Time-consuming processes are the placement of multiple layer insulations, the establishing the connections, the securing membranes against slippage on vertical surfaces and the formation of the conncetion of insulation against groundwater and soil moisture.

\section{Estimated costs}

The summarized cost estimate consists of three main parts: labour charges, material costs and machine charges. TERC Etalon time norms were used for the calculation of labour charges and assumed an overhead charge of $3000 \mathrm{Ft} /$ hour (9,5 €/hour).

\section{Comparison of waterproofing solutions for costs}

For cost estimates of water insulation solutions only those items were considered that differ in all three cases, so result data were used for comparison. It should be noted that for bituminous and plastic water insulation for the cellar masonry 38-cm-width Porotherm cellar brick-block was used, and small-size-brick for the insulation bearing wall. While for the coating insulation for the cellar wall 30-cm-width Leier concrete 
Contemporary achievements in civil engineering 23-24. April 2019. Subotica, SERBIA

formwork elements were used, in which the vertical watertight concrete structure can be created, but no insulation bearing wall is needed for this solution. (Fig.4)

\section{Material costs and labour charges for water insulations}

- Material costs and labour charges of the cellar walls and the insulation-bearing wall

- Charges for machines used for workflows

- Cost differencies due to the construction time

- Cost differences resulting from the construction time appear only in membrane water insulation solutions, because the time of implementation of the coating insulation solution is the shortest, so the other two can be compared to it.

- The machine charge is given just for coating insulation version because of the filling of formwork blocks with concrete.

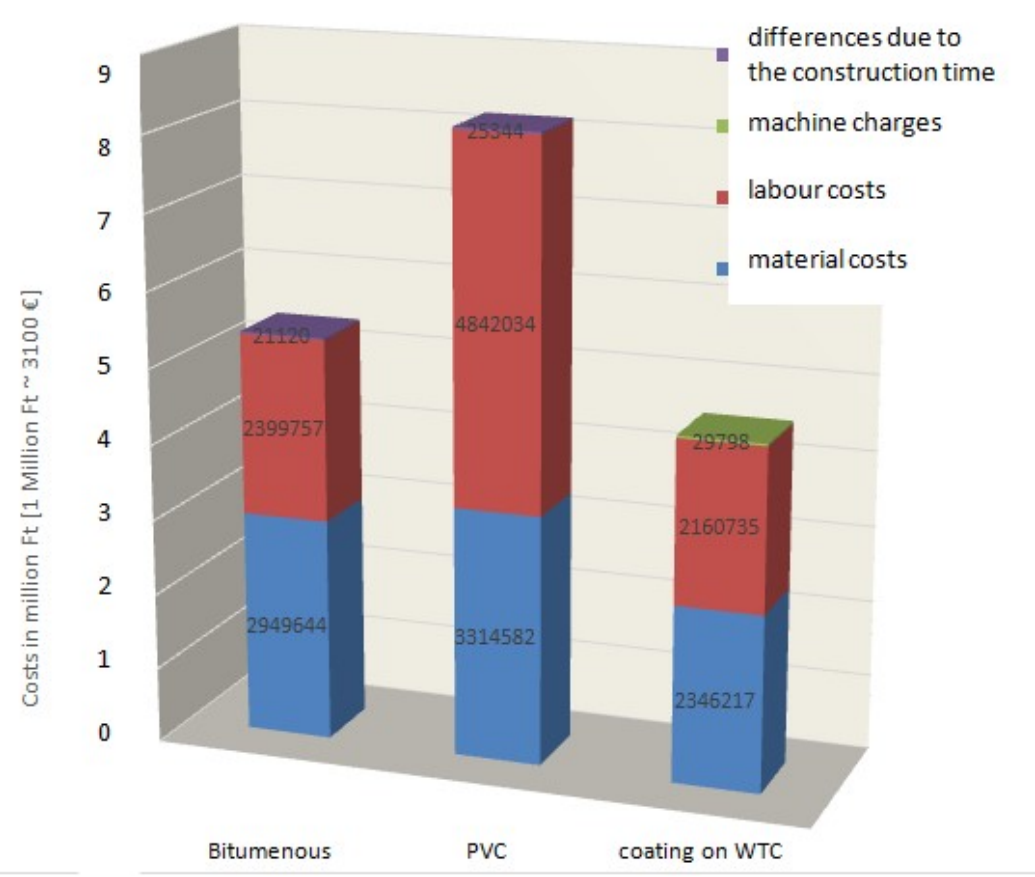

Figure 4. Comparison of water insulations by costs

Costs of water insulations compared to the whole buildings costs:

$\begin{array}{lll}\text { - } & \text { Bitumenous } & 6,021 \% \\ \text { - } & \text { PVC } & 9,156 \% \\ \text { - } & \text { Coating on WTC } & 5,042 \% .\end{array}$

\section{Costs of building the basement level}

The cost differences were examined in the groundwater-loaded construction site, depending on how deep position the building is, compared to the groundwater level. 
Савремена достигнућа у грађевинарству 23-24. април 2019. Суботица, СРБИЈА

The time of water table diminishing with pumps was taken into account as three months, assuming that the counter load-beraing structure of the building was completed during this time.

The basement with $1.87 \mathrm{~m}$ immersion depth was examined. In addition, that occasion was also analysed, when the building was raised with $1.69 \mathrm{~m}$ from the original design plain, so the basement needs to be insulated against just soil moisture. In the lifted version strip foundation is designed and the masonry had EPS insulation, because it is not underground. (Fig.5-7)

Costs of basement compared to the whole building construction costs:

- water insulation against subsoil water $\quad 24,2 \%$

- water insulation against soil moisture $\quad 11,4 \%$.

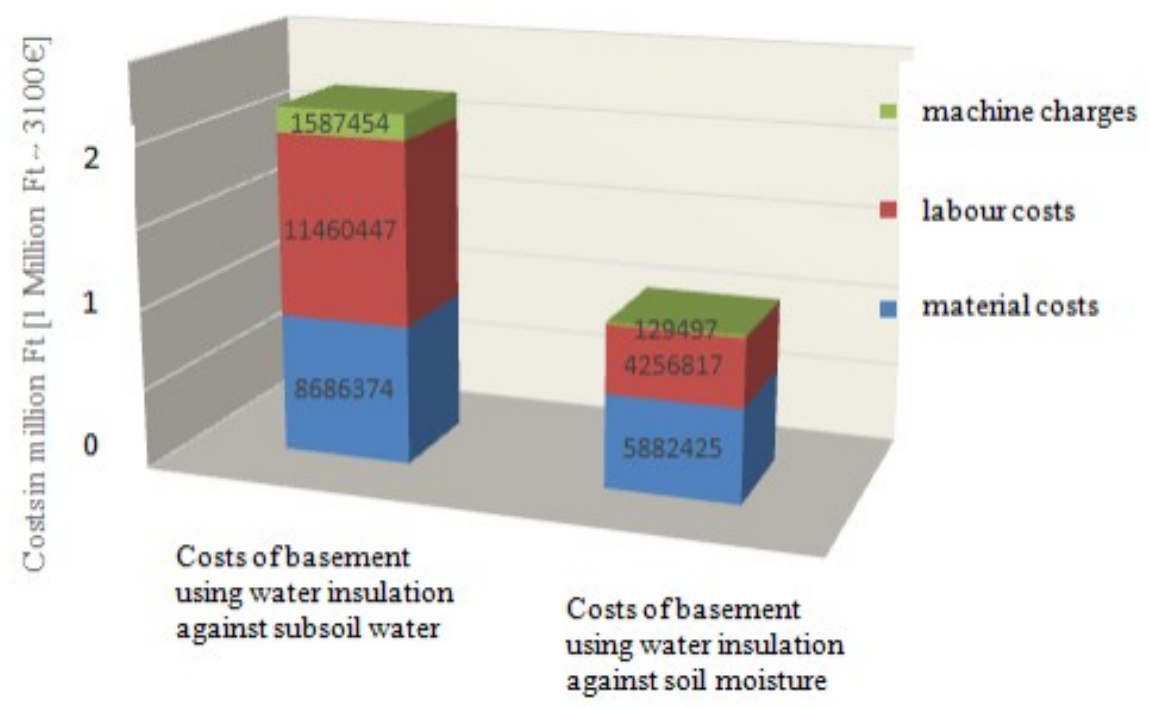

Figure 5. Comparison of water insulations against subsoil water and against soil moisture by costs

The comparison shows that the items in relation with the lowering of the building below the subsoil water level, as water table diminishing and earthwork ,.

Comparing the data, it can be shown that the best solution in terms of cost and time is to use formwork element filled by watertight concrete as a cellar wall, and the reinforced concrete mat (slab) foundation is made of a watertight concrete, and a positive-side waterinsulation is applied on the watertight concrete structure with flexible cement mortar coating insulation.

The most unfavorable is that version, when the cellar wall is made of cellar brick blocks, the insulating-bearing wall is made of small-sized-brick and the water insulation is made from plastic membrane.

The bitumenous membrane solution is between the two others, because it is closer to the $3^{\text {rd }}$ solution in terms of cost, but in terms of construction time it is closer to the plastic membrane waterproofing solution. 
Contemporary achievements in civil engineering 23-24. April 2019. Subotica, SERBIA

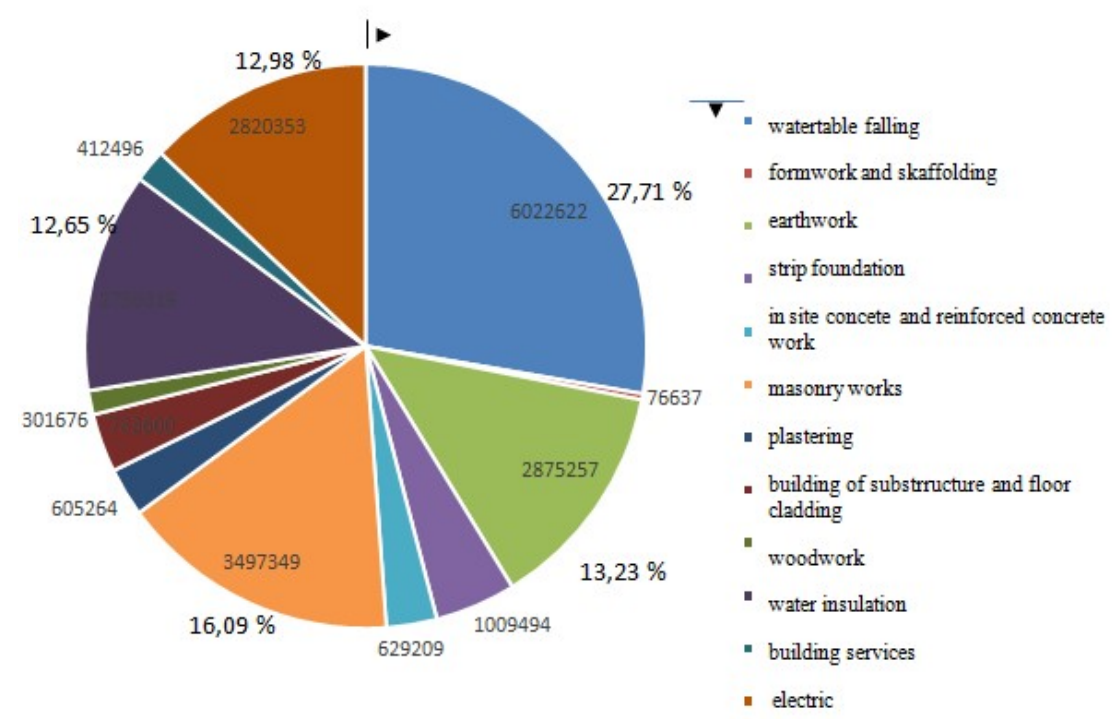

Figure 6. Working processes and their costs partioned to the whole basement in case of water insulation against subsoil water

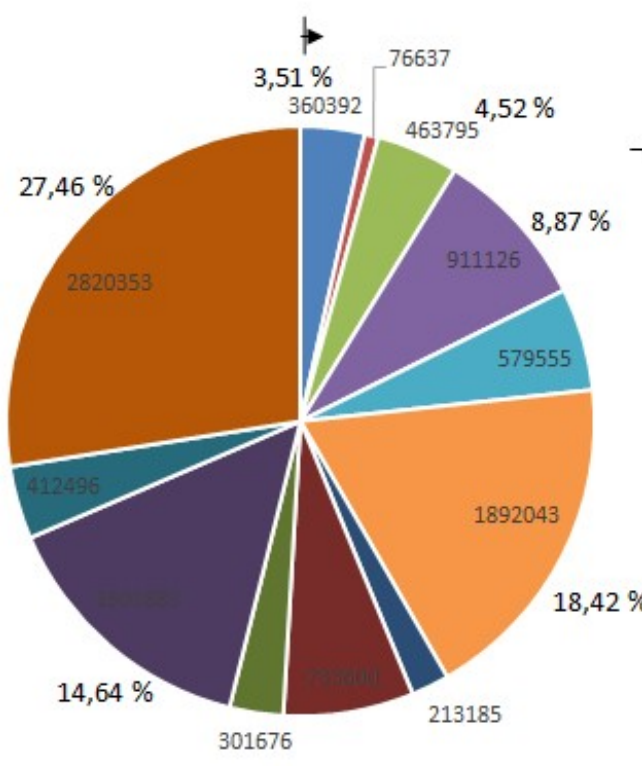

- watertable falling

- formwork and skaffolding

I. earthwork

- strip foundation

in site concete and reinforced concrete

- work

= masonry works

- plastering

- building of substructure and floor

cladding

- woodwork

- water insulation

- building services

- electric

Figure 7. Working processes and their costs partioned to the whole basement in case of water insulation against soil moisture 
Савремена достигнућа у грађевинарству 23-24. април 2019. Суботица, СРБИЈА

\section{SUMMARY}

Based on the analysis of the calculated results, it can be seen that the establishment of a basement level at a construction site loaded with groundwater is not economical, but often necessary. The presented results and correlations provide decision support where a basement is needed, for example at a smaller building site with subsoil water load.

Comparing all data, it can be clearly stated that the combination of watertight reinforced concrete and flexible cement-based mortar coating insulation provides the most favorable version, both in terms of cost and time of construction.

\section{REFERENCES}

[1] Balla,T.:Családi ház tervezése talajvízzel terhelt építési helyszínen (Design of residential building for building site with subsoil water effect), BScThesis, manuscript, 2017.

[2] http://www.iso-line.hu/ebook/EBOOK-Melyep.pdf, download 01.02.2017.

[3] Editor: Fülöp, Zs., Épületszigetelési kézikönyv (Building Insulation Manual)

(In Hungarian) Verlag Dashöfer Publisher Ltd. 2006 ISBN 9639313491

[4] http://www.iso-line.hu/ebook/EBOOK-Melyep.pdf, download 01.02.2017.

[5] http://www.fatrafol.cz/wp-content/uploads/2016/02/fatrafol-h-anglictina.pdf, download 01.02.2017.

[6] Osztroluczky, M., Térszín alatti vízszigetelések, Szerkezeti részletek, kivitelezés (Underground waterproofings, Structural details, construction) https://www.tankonyvtar.hu/hu/tartalom/tamop412A/2011_0060_epitestudoma ny/content/02-I-13/04.scorml, download 01.02.2017

[7] Osztroluczky, M.: Vízszigetelés (Waterproofing) (In Hungarian), CSER Publisher Ltd., 2010., ISBN: 9789632781341

[8] Tóth, E., Building Technology I (Építéstechnológia 1.), lecture notes, BME, 2016

[9] Széll, M., Building Construction I (Magasépítéstan I.), HEFOP lecture notes, BME, 2015

[10] https://www.aquaseal.hu/component/mtree/attachment/20/103.html, download 01.02.2017

[11] https://www.aquaseal.hu/component/mtree/attachment/265/103.html, download 01.02.2017 